\title{
Construction of Peptides Encompassing Multideterminant Clusters of Human Immunodeficiency Virus Envelope to Induce in Vitro T Cell Responses in Mice and Humans of Multiple MHC Types
}

\author{
Jay A. Berzofsky," C. David Pendleton," Mario Clerici," Jeffrey Ahlers, * Daniel R. Lucey," \\ Scott D. Putney," and Gene M. Shearer* \\ *Metabolism Branch and the ${ }^{\ddagger}$ Experimental Immunology Branch, National Cancer Institute, \\ National Institutes of Health, Bethesda, Maryland 20892; ${ }^{8}$ HIV Unit, Wilford Hall, Lackland AFB, \\ Texas 28236; and "Repligen Corporation, Cambridge, Massachusetts 02139
}

\begin{abstract}
To make synthetic peptide vaccines effective in a broad population of outbred humans, one would have to incorporate enough antigenic determinants to elicit recognition by $T$ cells of most HLA types. We have previously defined multideterminant regions of the human immunodeficiency virus (HIV) envelope that include overlapping determinants seen by proliferating $T$ cells of three or four haplotypes of mice. We have now tested the hypothesis that synthetic peptides encompassing such multideterminant regions will be recognized by $T$ cells of multiple murine MHC types as well as by human $T$ cells representing multiple HLA types. Six such peptides of 20-33 residues in length were prepared, and tested for their ability to stimulate $T$ cells from mice of four distinct MHC types immunized with recombinant envelope protein rgp160, as well as from 42 HIVinfected humans of different HLA types. Results identify several such peptides that are broadly recognized by mice of four H-2 types and by $52-73 \%$ of infected humans who still retain IL-2 productive responses to control recall antigens such as influenza $A$ virus or tetanus toxoid. $86 \%$ of such infected donors tested against at least three peptides respond to at least one of the six peptides, and $77 \%$ of an additional group of seropositives respond to a mixture of the peptides. Moreover, the peptides can be used to immunize mice to elicit $T$ cells reactive with the intact HIV envelope protein. These peptides therefore may be useful for both vaccine development in the broad human population, and diagnostic or prognostic use. (J. Clin. Invest. 1991. 88:876-884.) Key words: T lymphocyte • epitopes • vaccine $\bullet$ AIDS • HLA • HIV
\end{abstract}

\section{Introduction}

Whole virus vaccines, live attenuated or killed, offer the potential to stimulate immunity to the broadest array of antigenic determinants of the virus. However, they also may contain structures developed by the virus to evade the immune system, such as suppressive epitopes or masking carbohydrates, or

Address correspondence to Dr. Jay A. Berzofsky, Molecular Immunogenetics and Vaccine Research Section, Metabolism Branch, National Cancer Institute, NIH, Building 10, Room 6B-12, Bethesda, MD 20892.

Received for publication 28 August 1990 and in revised form 1 April 1991.

The Journal of Clinical Investigation, Inc

Volume 88, September 1991, 876-884 structures that elicit deleterious effects such as enhancing antibodies that increase viral infectivity $(1-4)$ or antibodies or $\mathrm{T}$ cells that may contribute to immunodeficiency in the case of HIV (5-8). In addition, for a retrovirus such as HIV, concerns about the safety of live attenuated or even killed whole viral vaccines may make them unacceptable to many potential recipients. Purified subunit vaccines have less safety risk, but still may suffer from the other problems of whole virus vaccines. Indeed, because the virus has evolved to evade the immune system, evolution may have favored the development of viral proteins that are hardly optimal as vaccines. Thus, in contrast to enzymes that have been honed by evolution to be the best structures for catalyzing their reactions, viral proteins may leave the scientist with considerable opportunities to improve on nature for the development of better vaccines (9).

To rationally design highly engineered synthetic or recombinant antiviral vaccines, we need considerable knowledge about the workings of the immune system, and in particular, about the immune response to structures expressed by the virus. We have initiated such an approach by attempting to identify antigenic determinants recognized by CTL (10-14) and by helper $T$ cells that would be required for either a CTL or an antibody response (15-18). However, a potential problem with the use of any single antigenic determinant is that $T$ cells recognize antigens in association with molecules encoded by the MHC of the host, and the MHC molecules of any given individual will bind and present only a subset of potential antigenic determinants that could be recognized by the species as a whole (19-21). This is true of humans as well as mice $(6,22-26)$. Therefore, in order to be useful in a broad outbred population such as humans, a vaccine would presumably have to contain multiple such determinants. Only limited data exist to indicate how many such determinants would have to be included. Although some concern has been raised that the number might be impractical to achieve, some data exist to suggest that as few as four such determinants could elicit responses in $85-90 \%$ of outbred humans (17). A few antigenic peptides have been identified that appear to be promiscuous in their recognition in association with many DR molecules $(27,28)$, perhaps because DR molecules share a conserved alpha chain, and in the mouse some determinants have been reported to be presented by three different I-A molecules that do not share alpha chains (29), or even by class II MHC molecules of different isotypes, such as I-A and I-E (30). However, it is not clear how common such promiscuous epitopes are.

In the course of locating the major $T$ cell stimulatory sites of the HIV envelope, we observed that there were regions in the sequence that contained multiple overlapping determinants 
seen by mice of different MHC haplotypes (18). Although the precise determinants seen by $T$ cells of each strain of mouse differed, each multideterminant region contained determinants that could stimulate $T$ cells of mice of three or four of the four MHC types tested. Therefore, we reasoned that peptides encompassing such multideterminant regions might be able to stimulate $T$ cells of many or most haplotypes of mice, and hopefully also $\mathrm{T}$ cells of humans of many HLA types. Thus, such multideterminant peptides might provide a means to circumvent this problem of MHC restriction in the design of synthetic vaccines. In the current study, we have tested this hypothesis by constructing six synthetic peptides of 20-33 residues each that correspond to the six multideterminant regions of HIV envelope protein localized in the mouse (18), and testing these peptides for their ability to stimulate $T$ cell responses in mice immunized with recombinant gp160 and in peripheral blood lymphocytes of humans infected with HIV. Although not all of the peptides were as widely recognized as expected, several such peptides were identified that were broadly recognized by both murine and human T cells of multiple $\mathrm{H}-2$ and HLA types. These peptides can also immunize mice for $\mathrm{T}$ cell responses to the intact HIV envelope protein, and so may be valuable components of a synthetic vaccine, and responses to them may be useful diagnostic or prognostic markers.

\section{Methods}

Synthesis of peptides. The six cluster peptides were synthesized on an automated peptide synthesizer (No. 430A; Applied Biosystems, Foster City, CA) utilizing t-boc chemistry (31). The peptides were cleaved from the resin with $\mathrm{HF}$ and were initially purified by molecular exclusion chromatography (P4 biogel; Bio-Rad Laboratories, Mountain View, CA). Reverse-phase HPLC was used to determine degree of purity and in cases requiring further purification. The HPLC separations were carried out on $\mu$ bondapack reverse-phase $\mathrm{C} 18$ analytical and preparative columns (Waters Associates, Milford, MA).

Mice. B10.BR/SgSn (H-2 $)$ and B10.D2/nSn (H-2 $)$ strains were obtained from The Jackson Laboratory (Bar Harbor, ME). B10.S(9R) $\left(\mathrm{H}-2^{14}\right)$ and B10.A(5R) (H-2 $\left.{ }^{\mathrm{is}}\right)$ strains were bred in our colony from breeders obtained from J. Stimpfling (McLaughlin Research Institute, Great Falls, MT) and The Jackson Laboratory, respectively.

gp160 preparation. Recombinant gp160 was prepared from cells infected with recombinant baculovirus expressing the gene for $\mathrm{gp} 160$ of the HTLV-IIIB isolate of HIV-1 as described (32).

$T$ cell proliferation assay (33). Mice were immunized subcutaneously in the tail with 20-30 $\mu$ g recombinant gp160 emulsified 1:1 in CFA (33). The mice were killed 8-11 d after immunization and their draining inguinal and periaortic lymph nodes were harvested and teased into single cell suspensions in complete $\mathrm{T}$ cell medium (34). Aliquots consisting of $4 \times 10^{5}$ cells were introduced into wells of 96well flat-bottomed culture plates containing various concentrations of the cluster peptides $(2,0.66,0.22 \mu \mathrm{M}$ final concentration in triplicate). After $4 \mathrm{~d}$ of incubation at $37^{\circ} \mathrm{C}$ in $5 \% \mathrm{CO}_{2},\left[{ }^{3} \mathrm{H}\right]$ thymidine $(1 \mu \mathrm{Ci})$ was added to all the wells. $24 \mathrm{~h}$ later the cells were harvested on an automated harvesting device (Skatron) and thymidine incorporated into DNA was determined by scintillation counting. The stimulation index is the ratio of cpm incorporated in the presence of antigen to cpm incorporated by cells cultured with medium alone.

$I L-2$ production by human $P B L$. For the assay of antigen-induced IL-2 production by human peripheral blood T cells, PBL from HIVseropositive asymptomatic blood donors were separated on lymphocyte separation medium (LSM; Organon Teknika Corp, Durham, NC), washed twice, counted, and resuspended at $3 \times 10^{6} / \mathrm{ml}$ in RPMI 1640 (Gibco Laboratories, Grand Island, NY) containing $50 \mathrm{U} / \mathrm{ml}$ penicillin and $2 \mathrm{mM}$ glutamine. In triplicate wells in a 96-well flat-bottomed plate (Costar, Cambridge, MA), $0.1 \mathrm{ml}$ of PBL was added per well and cultured without stimulation or stimulated with: (a) influenza A/Bangkok RX73 (final dilution 1:1,000); (b) PHA (Gibco Laboratories; final dilution 1:100); or (c) cluster peptides at a final concentration of 2.5 $\mu \mathrm{M}$. Pooled $\mathrm{AB}^{+}$plasma was added to each well (final dilution 1:20). The anti-IL-2 receptor antibody anti-Tac (a gift from Dr. T. A. Waldmann, NCI) was added to each well at the initiation of culture (final concentration, $5 \mu \mathrm{g} / \mathrm{ml}$ ) in order to block IL-2 consumption. The supernatants of the cell cultures were harvested $7 \mathrm{~d}$ later and frozen at $-20^{\circ} \mathrm{C}$. The supernatant IL-2 activity was assessed as the ability to stimulate the proliferation of the IL-2-dependent CTLL cell line as previously described (35).

\section{Results}

The synthetic multideterminant peptides (Table I) were designed to encompass the six multideterminant regions of gp 160 of HIV-1 strain IIIB identified in our earlier study in mice (18). Because these constitute clusters of determinants, we have called these "cluster peptides." Cluster peptide 1 consists of residues 109-134 in the numbering of Ratner et al. (36), encompassing overlapping peptides HP3-HP8 studied by Hale et al. (18), at least one of which stimulated mice of three MHC haplotypes, $\mathrm{H}-2^{\mathbf{k}}, \mathrm{H}-2^{\mathrm{d}}$, and $\mathrm{H}-2^{\mathrm{is}}$. Cluster peptide 2 consists of residues 324-356, corresponding to peptides HP19-HP20 that had been recognized by all four haplotypes studied, $\mathrm{H}-2^{\mathrm{k}, \mathrm{d}, \mathrm{i} \text {, and } \mathrm{t}^{4}}$ (18). Cluster peptide 3 consists of residues 428451, spanning HP26-HP29, at least one of which was seen by mice of each of the four haplotypes tested. Cluster peptide 4 spans residues 483-506 and peptides HP30-33, and T cells from mice of each of the four haplotypes responded to at least one of these peptides. Cluster peptide 5 consists of residues 787-820 encompassing HP47, 50, and 51, seen by three of four haplotypes (all but i5), and cluster peptide 6 spans residues 828-860 corresponding to peptides HP52-56, to at least one of which $\mathrm{T}$ cells of all four haplotypes responded (18). We have previously found that the smaller peptides HP5 (envT2) contained within cluster peptide 1, HP26 (envT1) contained with cluster peptide 3, and HP53 (envTH4.1) contained within cluster 6 elicit IL-2 production in peripheral blood lymphocytes of asymptomatic HIV-seropositive human patients (17).

Responses in lymph node $T$ cells of rgpl60-immune congenic mice. Each peptide was synthesized and purified as described in Materials and Methods, and tested for the ability to stimulate $T$ cell proliferative responses of mice of these four MHC types immunized with recombinant gp160. B10 congenic mice were used that differed only in their MHC type, but were otherwise genetically identical. The four mouse MHC types studied were chosen because they represent four independent MHC haplotypes that each express both an I-A and an I-E molecule, and differ from each other in both of these molecules. Thus the four strains together express eight different murine class II MHC molecules. It should be noted that the murine I-E molecules, like human DR molecules to which they are homologous, all share a conserved alpha chain, but differ in their beta chain, which accounts for all the polymorphism. Responses to most antigens differ among the several I-E and DR alleles, indicating the important role of the beta chain, despite the shared alpha chain.

Each peptide was studied in four independent experiments (or three for cluster peptide 3 , which was synthesized last), and the results were pooled by determining the geometric mean of the stimulation indices for a given peptide concentration in all four experiments (Fig. 1). Cluster peptides 3, 4, and 6 were the 
Table I. Sequences of Cluster Peptides and the Peptides They Encompass

\begin{tabular}{|c|c|}
\hline Peptides & Sequences \\
\hline PCLUS1 (109-128) & EQMHEDI ISLWDQSLKPCVK \\
\hline HP-3 & EQMHEDI ISLWDQSL \\
\hline HP-4 & QMHEDI ISLWDQSLK \\
\hline HP-5 & HEDIISLWDQSLK \\
\hline HP-6 & HEDI ISLWDQSLR \\
\hline HP-7 & DIISLWDQSLKPCVK \\
\hline PCLUS2 (324-356) & FVTIGKIGNMRQAHC (NIS) RAKWNNTLKQIDSKL \\
\hline HP-19 & FVTIGKIGNMRQAHC \\
\hline HP-20 & RAKWNNTLKQIDSKL \\
\hline PCLUS3 (428-451) & KQIINMWQEVGKAMYAPPISGQIR \\
\hline HP-26 & KQIINMWQEVGKAMYA \\
\hline HP-28 & NMWQEVGKAMYAPPI \\
\hline HP-29 & VGKAMYAPPISGQIR \\
\hline PCLUS4 (483-506) & RDNWRSELYKYKVVKIEPLGVAPT \\
\hline HP-30 & RDNWRSELYKYKVVK \\
\hline HP-33 & KYKVVKIEPLGVAPT \\
\hline PCLUS5 (787-820) & RIVELLGRRGWEALKYWWNLLQYWSQELKNSAVS \\
\hline HP-47 & RIVELLGRRGWEALK \\
\hline HP-50 & KYWWNLLQYWSQELK \\
\hline HP-51 & LLQYWSQELKNSAVS \\
\hline PCLUS6 (828-860) & AVAEGTDRVIEVVQGAYRAIRHIPRRIRQGLER \\
\hline HP-52 & AVAEGTDRVIEVVQG \\
\hline HP-53 & DRVIEVVQGAYRAIR \\
\hline HP-54 & VIEVVQGAYRAIRHI \\
\hline HP-55 & QGAYRAIRHIPRRIR \\
\hline HP-56 & AIRHIPRRIRQGLER \\
\hline
\end{tabular}

only ones to elicit a positive response in mice of all four MHC haplotypes. Cluster peptide 6 stimulated most strongly in $\mathrm{B} 10 . \mathrm{BR}\left(\mathrm{A}^{\mathrm{k}} \mathrm{E}^{\mathrm{k}}\right)$ and $\mathrm{B} 10 . \mathrm{A}(5 \mathrm{R})\left(\mathrm{A}^{\mathrm{b}} \mathrm{E}^{\mathrm{b}}\right)$ mice, and gave weaker but significantly positive and reproducible responses in
B10.S(9R) ( $\left.A^{s} E^{s}\right)$ and B10.D2 $\left(A^{d} E^{d}\right)$. Cluster peptide 4 stimulated most strongly in B10.S(9R), but was significantly and reproducibly positive in the other strains as well. Cluster peptide 3 stimulated very strongly in B10.S(9R), and gave weak
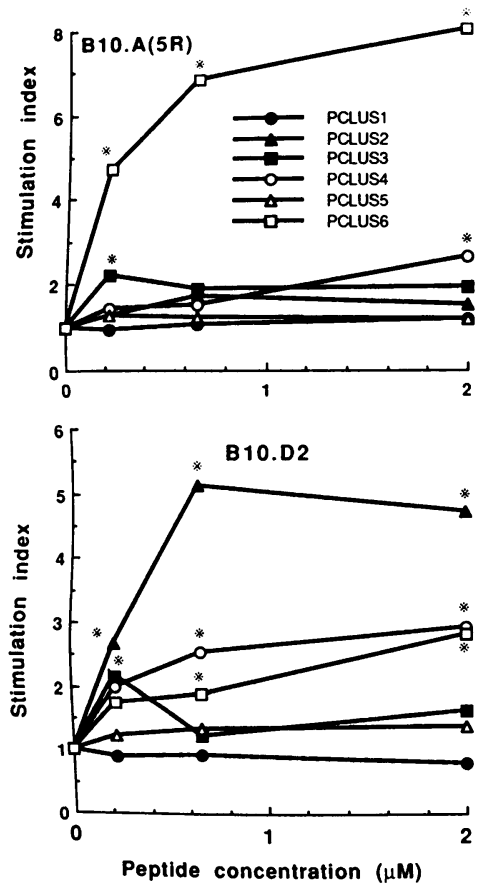
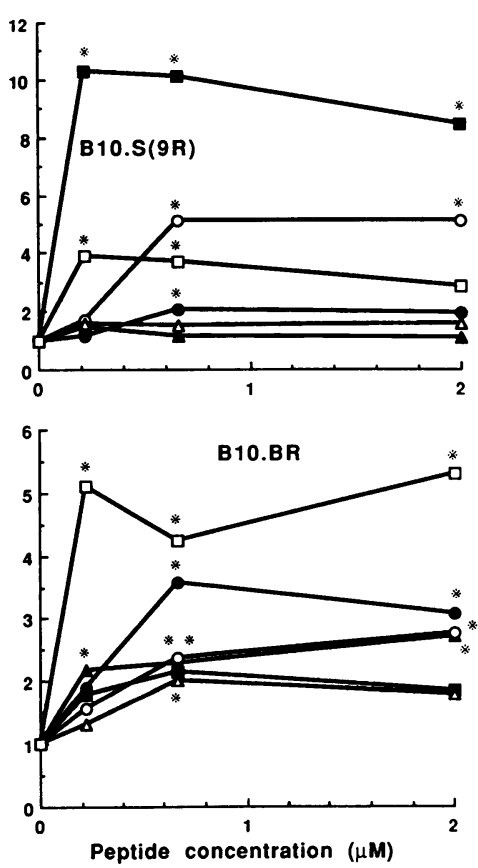

Figure 1. Proliferative response of $\mathrm{T}$ cells from gp160-immune mice to the six cluster peptides.

Mice were immunized subcutaneously with 20-30 $\mu \mathrm{g}$ of recombinant gp160 in CFA and draining lymph node cells assayed as described in Methods. Shown is the stimulation index as a function of peptide concentration in the culture, for four congenic strains of mice representing four distinct MHC haplotypes. Each value is the geometric mean stimulation index of 4 (or 3 in the case of cluster peptide 3 ) independent experiments. Although the results of the several experiments were qualitatively similar, the absolute values of the stimulation indices varied sufficiently as to make error bars difficult to read on these plots. Instead, values for which the mean stimulation index of all experiments is statistically significantly different from background (1) as measured by a Student's $t$ test $(P<0.05)$ are indicated with an asterisk. Results were considered positive only if this statistic was significant and the mean stimulation index of all experiments was $>2$. 
but statistically significant responses in the other three strains. The responses were more strongly positive in some experiments for these other strains, but some variability in magnitude of response reduced the geometric mean, although they remained statistically significant. These three peptides thus fulfill the predictions of the hypothesis (18) that by making an extended peptide encompassing overlapping antigenic determinants recognized by mice of multiple haplotypes, the resulting construct would be broadly recognized in all or most haplotypes.

The remaining three peptides elicited responses in fewer strains of mice than expected. Cluster peptide 2 was strongly positive in only two strains, B10.D2 and B10.BR, despite the fact that all four strains had recognized at least one site encompassed within this multideterminant region in our earlier study (18). Similarly, cluster peptide 1 was recognized by one strain, B10.BR, strongly, and by another strain, B10.S(9R), only marginally, despite the fact that three strains had recognized components of this multideterminant region. The most disappointing peptide was cluster peptide 5 , which failed to elicit a significant response in three strains, and gave only a marginal response in the fourth strain, B10.BR. These results suggest that the larger peptide is not simply the sum of its parts, but may fail to stimulate in strains that a smaller subcomponent would stimulate, perhaps because parts of the larger structure hinder interaction with MHC or T cell receptor, or because they cause the peptide to fold back on itself $(37-40)$, or because of different processing requirements.

Immunization with peptides to induce $T$ cells responding to intact gp160 in vitro. If these peptides are to be useful components of a vaccine, it is important that they not only be recognized by $\mathrm{T}$ cells immune to the HIV envelope protein $\mathrm{gp} 160$, but also that they be immunogenic to elicit $T$ cells in vivo that can respond to gp 160 . Of course, the immunizations could not be performed yet in the clinically relevant species, (uninfected) humans, but we wanted to be sure in strains of mice shown above to have $T$ cells responsive to these peptides, that we could immunize the mice in vivo with the peptides and elicit $T$ cells that responded to intact gp160 in vitro. We tested each peptide by immunizing mice of the strains responding best to that peptide based on the data in Fig. 1. B10.BR mice immunized with cluster peptide 1 , cluster peptide 5 , or cluster peptide 6 all produced $T$ cells that could be stimulated by recombinant gp160 in vitro (Fig. $2 \mathrm{~A}$ ). As a control for possible mitogenicity of the recombinant gp 160, T cells from B10.BR mice immunized with only CFA did not respond significantly to the gp160 in vitro (Fig. $2 A$ ). Therefore, the in vitro response was a result of immunization with the peptides. Similarly, $T$ cells from B10.S(9R) mice immunized with either cluster peptide 3 or cluster peptide 4 responded to recombinant gp160 in vitro, whereas similar mice immunized with adjuvant alone made a weak (mitogenic) response at only the highest concentration (Fig. 2 B). Likewise, B10.A(5R) mice immunized with cluster peptide 6 and B10.D2 mice immunized with cluster peptide 2 produced T cells responsive to gp 160 in vitro (Fig. 2, $C$ and $D$ ). All of these responses show high dose inhibition typical of $T$ cell proliferative responses, but in this case the decreased response at $30 \mu \mathrm{g} / \mathrm{ml}$ also may be due to some toxicity of the recombinant gp 160 preparation, which was solubilized in $8 \mathrm{M}$ urea and sodium dodecyl sulfate. Although the gp 160 was dialyzed before use, it is possible that residual detergent that is hard to remove was toxic at the highest dose. Nevertheless, the clear response at $10 \mu \mathrm{g} / \mathrm{ml}$ in all cases indicates that all six cluster peptides elicit in vivo $\mathrm{T}$ cells that can react with gp 160 .

Responses of peripheral blood $T$ cells from HIV-infected human subjects. Although there was precedent that peptides that elicit responses in murine $T$ cells also do so with human $T$ cells $(16,17,41-45)$, there were no data on human $T$ cells to some of the components of the cluster peptides. Therefore, this phase of the project was to test the hypothesis that peptides that elicit responses in mice of multiple MHC types were likely to elicit responses in humans of multiple HLA types as well. It was known from earlier work that peptide envT2 (residues 112124) contained within cluster peptide 1 , peptide envT1 (residues 428-443) contained within cluster peptide 3 , and peptide TH4.1 (residues 834-848, also known as HP53) contained within cluster peptide 6 all stimulated responses in $50-67 \%$ of HIV-infected human subjects who could still respond to positive-control recall antigens such as influenza A virus (flu) or tetanus toxoid (17). However, we had no prior experience with peptides from these other multideterminant regions in humans. Because the proliferative and IL-2 productive responses to soluble protein antigens are lost early in HIV infection, frequently when patients are still asymptomatic and have normal $\mathrm{CD}^{+}$cell numbers $(17,35,46)$, responses to flu and tetanus toxoid were used as positive controls in these experiments to exclude donors unresponsive to all such recall protein antigens.

All six cluster peptides were tested for the ability to stimulate IL-2 production by peripheral blood T cells from a series of HIV-seropositive but asymptomatic volunteers, as well as HIV-seronegative controls. All 15 seronegative controls responded to the control recall antigen influenza virus (flu), but only 42 of the $59 \mathrm{HIV}$-seropositive donors responded to flu. Because of our previous experience that seropositive donors who fail to respond to control recall protein antigens such as flu or tetanus toxoid also fail to respond to HIV peptides (17), the 17 donors who failed to respond to flu were excluded from further study. Because some of the peptides had not been purified at the time some of the donors were available, these peptides were tested on cells from a subset of the donors. Results for the six cluster peptides in the $42 \mathrm{HIV}$-seropositive flu-positive donors and 15 control HIV-seronegative donors are given in Table II, and summarized in Table III.

All six cluster peptides stimulated IL-2 production in more than half of the HIV-seropositive, flu-positive donors. Cluster peptides 1 and 3 were most broadly recognized, giving responses in 64 and 73\% of the donors. Cluster peptides 2, 5, and 6 were close seconds, positive in 58,59 , and $58 \%$ of the donors, respectively. The least broadly recognized was cluster peptide 4 , but even this stimulated $52 \%$ of the donors. In contrast, none or only one of the control seronegative donors responded to any of the peptides except cluster peptide 2 , which stimulated 2 of the 15 control donors (13\%). Thus, none of the peptides were nonspecifically mitogenic. The human donors were unrelated Air Force personnel, originally from different parts of the United States, and of diverse HLA types. Because of limited availability of blood, only 13 of the $\mathrm{HIV}^{+}$donors could be HLA-typed, and only 8 could be typed for DR and DQ, which require more blood (Table IV). In this limited sample, no correlation between response to any peptide and any HLA type could be detected. We conclude that all of these cluster peptides fulfill the hypothesis that peptides that are broadly recognized 

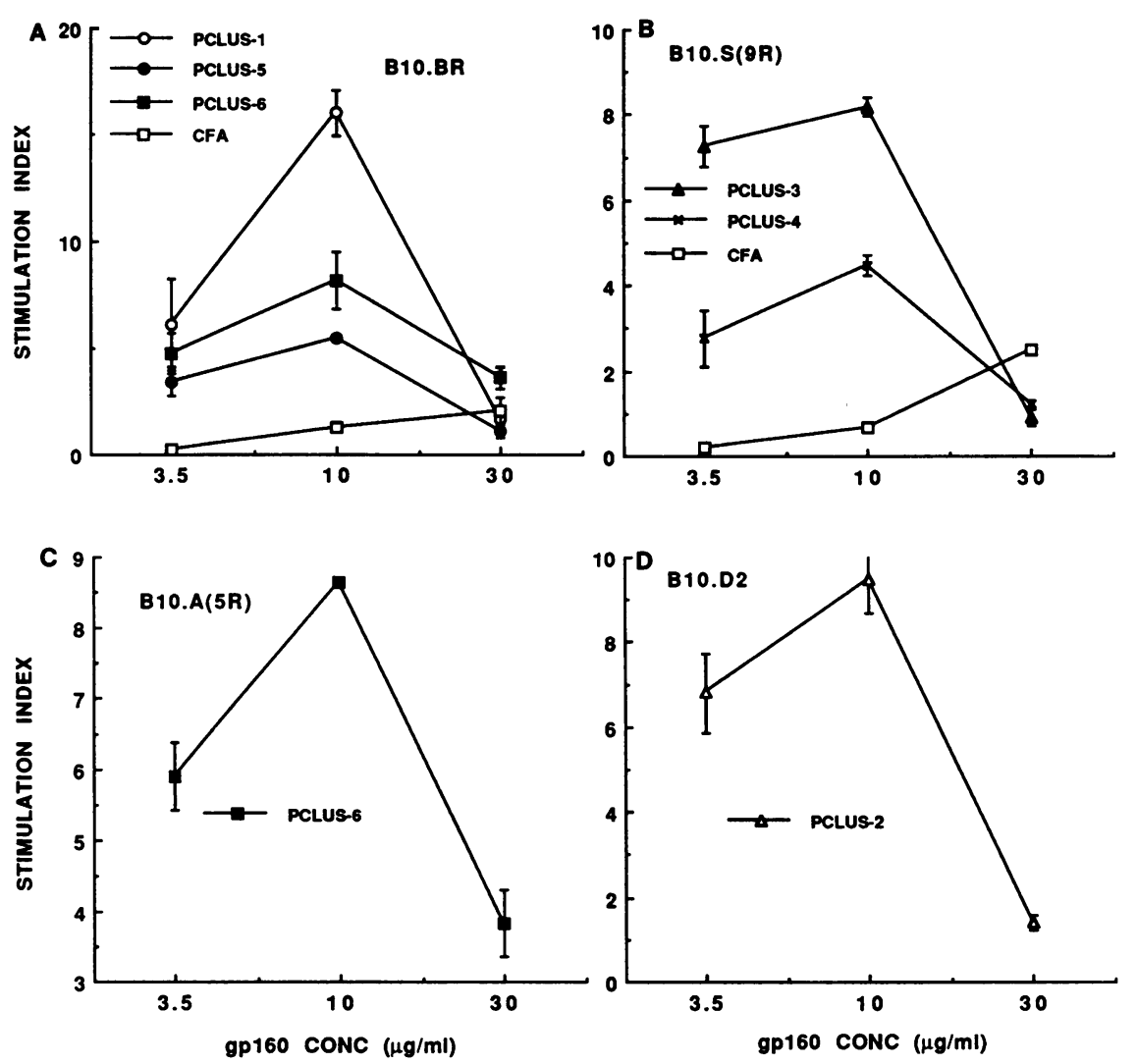

Figure 2. Immunization with cluster peptides in adjuvant, but not adjuvant alone, elicits $\mathrm{T}$ cells proliferating in response to whole $\mathrm{gp} 160$. Mice of the four strains shown were immunized subcutaneously in the tail with 8-10 $\mathrm{nmol}$ of the indicated cluster peptide in a 1:1 emulsion with CFA, final volume per mouse $50 \mu$ l except for cluster peptide 2 , which was in $75 \mu \mathrm{l} .12 \mathrm{~d}$ later, the draining lymph nodes were harvested from two mice of each group (strain and peptide combination) and assayed as described in Methods. Results are shown as stimulation indices, the ratio of experimental cpm over cpm from stimulation with medium alone, which ranged from 3,000-7,000 cpm for the different groups.

by murine $\mathrm{T}$ cells are likely to be broadly recognized by human $\mathrm{T}$ cells as well. Indeed, some of the peptides, such as cluster peptides 1 and 5, were more broadly recognized by humans of diverse HLA types than by different strains of inbred mice tested.

The results in Table II indicate that $31(86 \%)$ of the 36 donors responsive to the positive control antigen flu who were tested with at least three peptides responded to at least one of them. To further test the extent of the population that could respond, an additional $13 \mathrm{HIV}$-seropositive donors responsive to flu, not overlapping with the donors listed in Table II, were tested for their response to a mixture of the six cluster peptides, each at $2.5 \mu \mathrm{M}$. 10 of these 13 , or $\sim 77 \%$, responded, whereas none of four seronegative donors responded to the mixture of peptides, although all four responded to flu (data not shown). Although it is possible that the peptides in the mixture may compete with each other for binding to some MHC molecules, given the small sample sizes in the two groups studied, there is probably not a statistically significant difference between the fraction responding to at least one peptide in the first group and the fraction responding to the mixture in the second. In either case, we conclude that a sizable majority of people are capable of making $\mathrm{T}$ cell responses to these peptides.

\section{Discussion}

We set out to test the hypotheses that by encompassing multideterminant regions of the HIV-1 envelope protein gp 160 with synthetic peptides we could construct antigens that would be recognized by mice of multiple $\mathrm{H}-2$ types, and second, that such cluster peptides might also be recognized by human $T$ cells from HIV-infected patients representing a broad array of HLA types. Both of these hypotheses were fulfilled, at least in part. Three of the cluster peptides stimulated immune $\mathrm{T}$ cells from all four independent $\mathrm{H}-2$ types of congenic mice as predicted. For example, whereas peptide HP53 was positive in two strains, B10.BR and B10.A(5R), and HP55 was strongly positive in B10.D2 and B10.A(5R), and HP56 was positive in B10.BR and B10.S(9R) (18), cluster peptide 6 which spans these was positive in all four strains. Similarly, whereas peptide HP26 (also called envT1 in some papers) did not elicit a response in $\mathrm{H}-2^{\mathrm{b}}$ or $\mathrm{B} 10 . \mathrm{A}(5 \mathrm{R})$ mice $(15,18)$, cluster peptide 3 , spanning HP26 to HP29, did stimulate T cells from B10.A(5R), presumably because it also contained HP29, which was positive in this strain (18). However, the other three peptides stimulated $T$ cells from fewer strains than expected. These three peptides indicate that a larger peptide does not necessarily mediate all of the functions of its subcomponents, possibly because of the additional sequence of the peptide can fold back on itself and sterically obstruct interaction with the MHC molecule or $\mathrm{T}$ cell receptor, or can otherwise alter the conformation of the determinant in question. Similar findings in model systems such as myoglobin, lysozyme, or staphylococcal nuclease have suggested that such hindering structures do occur (3740). Also, the fact that whole protein immunization elicits $T$ cells that can respond to the smaller synthetic peptides but not some of the larger ones containing these suggests that the larger peptides may be processed differently from the whole protein. Such differences may be due to differences in accessibility of certain bonds caused by different conformational preferences of the longer peptides compared with the whole protein. Therefore, because it is not yet possible to predict such obstructive 
Table II. IL-2 Production by T Cells from HIV-seropositive and -seronegative Human Blood Donors

\begin{tabular}{|c|c|c|c|c|c|c|c|}
\hline \multirow{2}{*}{$\begin{array}{c}\text { Donor } \\
\text { number }\end{array}$} & \multirow[b]{2}{*}{ Flu } & \multicolumn{6}{|c|}{ Cluster peptide number } \\
\hline & & 1 & 2 & 3 & 4 & 5 & 6 \\
\hline \multicolumn{8}{|l|}{ HIV $^{+}$Donors } \\
\hline 317 & 64.5 & 11.4 (NS) & 1.9 & NT & NT & NT & 29.7 \\
\hline 453 & 91.4 & 5.0 (NS) & 30.2 & NT & NT & NT & 16.3 \\
\hline 909 & 6.3 & 7.8 & 9.1 & NT & NT & NT & 9.4 \\
\hline 360 & 4.0 & 2.7 & 2.2 & NT & 2.3 & 2.8 & 3.3 \\
\hline 396 & 3.2 & 2.4 & 1.7 & NT & 2.2 & 7.5 & 3.1 \\
\hline 131 & 8.2 & 2.8 & 5.7 & NT & 1.4 & 2.3 & 5.2 \\
\hline 208 & 5.1 & 0.5 & 1.9 & NT & 1.2 & 0.1 & 0.4 \\
\hline 335 & 26.4 & 9.2 & 9.0 & NT & 9.0 & 9.4 & 6.4 \\
\hline 69 & 3.6 & 2.3 & 4.7 & NT & 0.2 & 2.4 & 1.6 \\
\hline 556 & 3.4 & 4.0 & 0.8 & NT & 1.0 & 2.1 & 1.5 \\
\hline 212 & 37.9 & 21.9 & 13.1 & NT & 0.8 & 0.8 & 1.2 \\
\hline 375 & 15.1 & 6.1 & 0.8 & NT & 0.2 & 0.2 & 5.7 \\
\hline 564 & 7.8 & 4.8 & 4.1 & NT & 1.7 & 2.8 & 2.9 \\
\hline 83 & 26.5 & 2.7 & 13.3 & NT & 8.4 & 1.8 & 1.0 \\
\hline 621 & 112.3 & 54.8 & 39.1 & NT & 0.6 & 36.3 & 14.4 \\
\hline 920 & 5.5 & 2.1 & 1.7 & NT & 0.5 & 1.3 & 2.2 (NS) \\
\hline 90 & 16.0 & 2.4 & 4.4 & 2.9 & 7.0 & 4.2 & 1.5 \\
\hline 224 & 3.1 & 1.3 & 1.4 & NT & 3.2 & 1.6 & 1.0 \\
\hline 430 & 7.9 & 3.1 & 2.8 & NT & 1.3 & 2.5 & 3.0 \\
\hline 698 & 6.5 & 2.6 & 4.7 & NT & 3.4 & 4.6 & 4.4 \\
\hline 399 & 6.7 & 1.7 & 1.4 & NT & 1.0 & 1.3 & 1.2 \\
\hline 923 & 7.9 & 2.4 & 1.6 & NT & 1.4 & 2.8 & 3.0 \\
\hline 75 & 14.2 & 0.8 & 5.4 & 4.8 & 0.4 & 3.6 & 5.0 \\
\hline 281 & 16.1 & 5.9 & 1.1 & NT & 3.3 & 7.9 & 1.1 \\
\hline 357 & 26.1 & 2.0 (NS) & 5.8 & NT & 12.2 & 6.3 & 5.1 \\
\hline 395 & 36.7 & 4.1 & 7.9 & NT & 11.3 & 2.3 (NS) & 7.0 \\
\hline 916 & 36.2 & 12.0 & 2.7 & NT & 3.8 & 11.7 & 5.8 \\
\hline 232 & 7.5 & 2.1 (NS) & 0.3 & NT & NT & NT & 1.9 \\
\hline 755 & 8.6 & 0.5 & 0.2 & NT & NT & NT & 1.8 \\
\hline 193 & 22.3 & 1.4 & 13.2 & NT & NT & NT & 54.9 \\
\hline 911 & 15.8 & 2.1 & 3.1 & NT & NT & NT & 3.1 \\
\hline 419 & 12.9 & 0.9 & 6.6 & NT & NT & 0.9 & 1.7 \\
\hline 914 & 9.3 & 0.4 & 0.5 & NT & NT & 0.3 & 0.5 \\
\hline 132 & 18.9 & 1.8 & 1.4 & 1.5 & 4.9 & 1.4 & NT \\
\hline 504 & 20.4 & 5.3 & 13.8 & 9.6 & 13.8 & 9.1 & NT \\
\hline 933 & 17.7 & 9.6 & 1.4 & 7.7 & 9.7 & 0.3 & NT \\
\hline 213 & 6.8 & NT & NT & 0.5 & NT & NT & NT \\
\hline 421 & 12.7 & NT & NT & 10.9 & NT & NT & NT \\
\hline 604 & 6.1 & NT & NT & 1.7 & NT & NT & NT \\
\hline 851 & 5.6 & NT & NT & 8.9 & NT & NT & NT \\
\hline 904 & 22.5 & NT & NT & 8.1 & NT & NT & NT \\
\hline 906 & 3.1 & NT & NT & 5.7 & NT & NT & NT \\
\hline \multicolumn{8}{|c|}{ HIV $^{-}$Controls } \\
\hline $\mathrm{HCl}$ & 6.6 & 0.8 & 1.0 & NT & NT & NT & 3.1 \\
\hline HC2 & 8.4 & 0.2 & 0.4 & NT & 2.5 & 0.2 & 0.1 \\
\hline HC3 & 2.9 & 0.3 & 0.7 & NT & 0.4 & 0.3 & 0.6 \\
\hline HC4 & 7.3 & 1.0 & 0.9 & NT & 0.1 & 0.7 & 1.1 \\
\hline HC5 & 10.9 & 0.6 & 2.2 & NT & 0.5 & 0.2 & 1.9 \\
\hline HC6 & 7.0 & 0.7 & 0.5 & 1.0 & NT & 0.3 & 0.7 \\
\hline HC7 & 3.9 & 1.8 & 0.9 & 0.8 & NT & 1.1 & 1.0 \\
\hline HC8 & 4.4 & 0.9 & 0.8 & 0.2 & NT & 1.4 & 0.7 \\
\hline HC12 & 6.2 & 0.7 & 0.2 & 0.9 & 0.1 & 0.1 & NT \\
\hline HCbbl & 6.3 & 0.7 & 0.7 & 0.4 & 1.0 & 0.5 & NT \\
\hline $\mathrm{HCbb2}$ & 17.6 & 0.2 & 0.4 & 0.2 & 0.7 & 0.6 & 0.4 \\
\hline $\mathrm{HCbb3}$ & 5.5 & 0.6 & 0.1 & 0.2 & 0.1 & 0.4 & 0.4 \\
\hline HCbb4 & 74.6 & 1.3 & 1.9 & 0.9 & 0.7 & 0.8 & 0.5 \\
\hline HCbb5 & 6.7 & 2.9 & 15.3 & 1.2 & 0.2 & 0.5 & 0.7 \\
\hline HCbb6 & 6.5 & 1.1 & .8 & 1.2 & 1.2 & 1.8 & NT \\
\hline
\end{tabular}

Values shown are stimulation indices for proliferation of an IL-2-dependent CTLL cell line in the presence of a 1:2 dilution of culture supernatant from triplicate cultures of PBL from the indicated donor with a $2.5 \mu \mathrm{M}$ concentration of the indicated peptide, as described in Methods. All of the seropositive donors and controls studied were responsive to the positive control recall protein antigen flu. For a value to be considered positive, it had to simultaneously meet two criteria: The replicates had to be statistically significantly different from the control replicates for that donor by Student's $t$ test $(p<0.05)$, and the stimulation index had to be greater than twice the medium control. Six cases marked NS were stimulation indices $>2.0$, which were not counted as positives because the replicates were not statistically significant. In several cases with SI $<2.0$, the replicates were significantly different from background, but these were not considered positive because of the low stimulation index. The requirement for both criteria is thus more conservative than using either alone. 
Table III. Summary of Human T Cell IL-2 Responses to Cluster Peptides

\begin{tabular}{lcccccc}
\hline & $\begin{array}{c}\text { Cluster } \\
\text { peptide 1 }\end{array}$ & $\begin{array}{c}\text { Cluster } \\
\text { peptide 2 }\end{array}$ & $\begin{array}{c}\text { Cluster } \\
\text { peptide 3 }\end{array}$ & $\begin{array}{c}\text { Cluster } \\
\text { peptide 4 }\end{array}$ & $\begin{array}{c}\text { Cluster } \\
\text { peptide 5 }\end{array}$ & $\begin{array}{c}\text { Cluster } \\
\text { peptide 6 }\end{array}$ \\
\hline $\mathrm{HIV}^{+} \mathrm{Flu}^{+}$donors & $23 / 36$ & $21 / 36$ & $8 / 11$ & $14 / 27$ & $17 / 29$ & $19 / 33$ \\
& $64 \%$ & $58 \%$ & $73 \%$ & $52 \%$ & $59 \%$ & $58 \%$ \\
$\mathrm{HIV}^{-} \mathrm{Flu}^{+}$controls & $1 / 15$ & $2 / 15$ & $0 / 10$ & $1 / 11$ & $0 / 14$ & $0 \%$ \\
& $7 \%$ & $13 \%$ & $0 \%$ & $9 \%$ & $8 \%$ \\
\hline
\end{tabular}

See legend to Table II for criteria for positivity.

interactions or processing differences, it is necessary to test any such construct empirically. Nevertheless, the fact that three of the peptides stimulated responses in mice of all four $\mathrm{H}-2$ types indicates that it is possible to make such broadly recognized constructs, and that they do not need to be more than $\mathbf{3 0}$ or $\mathbf{3 5}$ residues to do so. Thus, such peptides are still within the easily accessible range of solid-phase peptide synthesis, and are also small enough to be able to exclude potentially deleterious sites on the native viral protein, providing a potential advantage over intact viral subunit vaccines. Moreover, the peptides are also immunogenic in vivo, and elicit $T$ cells that respond to intact HIV envelope protein, as one would want a vaccine to do. Therefore, although these peptides alone do not constitute a vaccine, these results are encouraging for the future development of rationally designed synthetic or recombinant viral vaccines for HIV.

Second, the broad recognition of these cluster peptides by from 52 to $73 \%$ of outbred, HLA-diverse infected human donors indicates that it is possible to develop peptides of reasonable size that will be broadly useful in the large outbred human population. Indeed, 31 (86\%) of the $36 \mathrm{HIV}$-infected donors who were tested with three or more peptides and who could still respond to the control antigen flu were responsive to at least one of the six cluster peptides, despite the fact that many of them were not tested with all six peptides. Confirming this high frequency of responsiveness, we found that $77 \%$ of an additional group of $13 \mathrm{HIV}$-seropositive donors, still responsive to flu as a positive control, responded to a mixture of all six pep-

Table IV. HLA Typing of HIV-seropositive Donors

\begin{tabular}{rccccc}
\hline Donor & HLA-A & HLA-B & HLA-C & DQ & DR \\
\hline 90 & 24,29 & 7,44 & 2,3 & & \\
208 & $9(23), 32$ & 7,17 & 3 & 1,2 & 2,3 \\
281 & 23,33 & 17 & 3 & 2 & 1,3 \\
375 & 2,24 & 35,61 & 2,4 & 1 & 3 \\
131 & 1,3 & 7,62 & 3 & 1,3 & 2,4 \\
909 & 30,33 & 17 & 3 & 1 & 1,2 \\
232 & 9,31 & 14,18 & 3 & 2,3 & 3,5 \\
755 & 2,28 & 35,15 & 2,3 & 1,3 & 2,4 \\
75 & 30 & 7,18 & 2 & & \\
360 & 2,31 & 51 & 2 & & \\
317 & 28 & 12 & 3 & 1,2 & 2,4 \\
395 & 1,3 & 7,8 & - & & \\
\hline
\end{tabular}

tides. We conclude that it will not require an unwieldy number of peptides to stimulate a response in most of the human population, so that the problem of MHC restriction can be overcome. These cluster peptides may be useful components of a vaccine, and may also be useful diagnostic or prognostic reagents. Preliminary results indicate that some seronegative but HIV-infected individuals may develop IL-2-productive T cell responses to these peptides before they seroconvert (46a). It is expected from the sequence of events in the antibody response that helper $T$ cells should arise before antibodies. Thus, these reagents may be useful for screening donors for infection when individuals at risk remain negative by antibody tests.

It should be noted that these high percentages of response were observed despite the fact that the subjects tested were presumably infected with a large number of different substrains of HIV-1. Four of the six cluster peptides have sequences that are relatively conserved among North American and European isolates of HIV-1, and the others, cluster peptides 2 and 6, span boundaries between conserved and variable sequences (47). It is also of interest that five of the peptides, all but cluster peptide 4 , contain regions that would be amphipathic if folded as a helix, consistent with the preponderance of such structures among immunodominant $T$ cell epitopes (48-51).

Although these peptides by themselves do not constitute a complete vaccine, these results give hope that it will be possible to design a synthetic or recombinant vaccine that can exclude potentially harmful regions of viral proteins while retaining the ability to induce an immune response in most of the human population. Synthetic peptide or recombinant protein vaccines are known to be able to elicit antibodies and helper $\mathrm{T}$ cells, but until recently it would have been necessary to make a synthetic gene encoding the engineered vaccine and express this in a live viral vector such as vaccinia to be able to elicit $\mathrm{CD} 8^{+} \mathrm{CTL}(52$, 53). However, it has been recently demonstrated that incorporation of purified proteins into immunostimulatory complexes (ISCOMs) of quil A and cholesterol produces a nonliving vaccine that can elicit in vivo $\mathrm{CD}^{+}$, class I MHC-restricted CTL responses (54). Similarly, attachment of a lipid tail to short synthetic peptides allows induction of $\mathrm{CD}^{+} \mathrm{CTL}$ in vivo (55). Thus, the hope of developing a synthetic vaccine that can elicit all three major arms of the immune response now appears realistic. Because viral proteins may be naturally selected during evolution to evade the immune response, the ability to construct immunogenic rationally designed and engineered vaccines may make it possible to produce vaccines that are more immunogenic and have fewer deleterious side effects than any natural subunit vaccine or even whole virus. 


\section{Acknowledgments}

We thank Dr. Richard Hodes (National Cancer Institute) and Dr. Ira Berkower (Bureau of Biologics, Food and Drug Administration) for critical reading of the manuscript and helpful suggestions. The opinions expressed herein are the private views of the authors and not to be construed as official or as reflecting the views of the Department of Defense or the Department of the Air Force.

\section{References}

1. Takeda, A., C. U. Tuazon, and F. A. Ennis. 1988. Antibody-enhanced infection by HIV-1 via Fc receptor-mediated entry. Science (Wash. DC) 242:580-583.

2. Robinson, W. E. Jr., D. C. Montefiori, W. M. Mitchell, A. M. Prince, H. J. Alter, G. R. Dreesman, and J. W. Eichberg. 1989. Antibody-dependent enhancement of human immunodeficiency virus type 1 (HIV-1) infection in vitro by serum from HIV-1 infected and passively immunized chimpanzees. Proc. Natl. Acad. Sci. USA. 86:4710-4714.

3. Robinson, W. E. Jr., T. Kawamura, M. K. Gorny, D. Lake, J.-Y. Xu, Y. Matsumoto, T. Sugano, Y. Masuho, W. M. Mitchell, E. Hersh, and S. Zola Pazner. 1990. Human monoclonal antibodies to the human immunodeficiency virus type 1 (HIV-1) transmembrane glycoprotein gp4l enhance HIV-1 infection in vitro. Proc. Natl. Acad. Sci. USA. 87:3185-3189.

4. Halstead, S. B. 1988. Pathogenesis of dengue: challenges to molecular biology. Science (Wash. DC). 239:476-481.

5. Weinhold, K. J., H. K. Lyerly, S. D. Stanley, A. A. Austin, T. J. Matthews, and D. P. Bolognesi. 1989. HIV-1 gp120-mediated immune suppression and lymphocyte destruction in the absence of viral infection. J. Immunol. 142:30913097.

6. Siliciano, R. F., L. Trebor, C. Knall, R. W. Karr, P. Berman, T. Gregory, and E. L. Reinherz. 1988. Analysis of host-virus interactions in AIDS with antigp120 T cell clones: effect of HIV sequence variation and a mechanism for CD4+ cell depletion. Cell. 54:561-575.

7. Mittler, R. S., and M. K. Hoffmann. 1989. Synergism between HIV gp120 and gp120-specific antibody in blocking human T cell activation. Science (Wash. DC). 245:1380-1382.

8. Golding, H., G. M. Shearer, K. Hillman, P. Lucas, J. Manischewitz, R. A Zajac, M. Clerici, R. E. Gress, N. R. Boswell, and B. Golding. 1989. Common epitope in human immunodeficiency virus (HIV) 1-GP41 and HLA class II elicits immunosuppressive autoantibodies capable of contributing to immune dysfunction in HIV 1-infected individuals. J. Clin. Invest. 83:1430-1435.

9. Berzofsky, J. A. 1988. The structural basis of antigen recognition by $T$ lymphocytes: Implications for vaccines. J. Clin. Invest. 82:1811-1817.

10. Takahashi, H., J. Cohen, A. Hosmalin, K. B. Cease, R. Houghten, J. Cornette, C. DeLisi, B. Moss, R. N. Germain, and J. A. Berzofsky. 1988. An immunodominant epitope of the HIV gp 160 envelope glycoprotein recognized by class I MHC molecule-restricted murine cytotoxic T lymphocytes. Proc. Natl. Acad. Sci. USA. 85:3105-3109.

11. Takahashi, H., S. Merli, S. D. Putney, R. Houghten, B. Moss, R. N. Germain, and J. A. Berzofsky. 1989. A single amino acid interchange yields reciprocal CTL specificities for HIV gp160. Science (Wash. DC). 246:118-121.

12. Takahashi, H., R. Houghten, S. D. Putney, D. H. Margulies, B. Moss, R. N. Germain, and J. A. Berzofsky. 1989. Structural requirements for class-I MHC molecule-mediated antigen presentation and cytotoxic T-cell recognition of an immunodominant determinant of the HIV envelope protein. J. Exp. Med. 170:2023-2035.

13. Takahashi, H., R. N. Germain, B. Moss, and J. A. Berzofsky. 1990. An immunodominant class I-restricted cytotoxic $T$ lymphocyte determinant of human immunodeficiency virus type 1 induces CD4 class II-restricted help for itself. J. Exp. Med. 171:571-576.

14. Hosmalin, A., M. Clerici, R. Houghten, C. D. Pendleton, C. Flexner, D. R. Lucey, B. Moss, R. N. Germain, G. M. Shearer, and J. A. Berzofsky. 1990. An epitope in HIV-1 reverse transcriptase recognized by both mouse and human CTL. Proc. Natl. Acad. Sci. USA. 87:2344-2348.

15. Cease, K. B., H. Margalit, J. L. Cornette, S. D. Putney, W. G. Robey, C Ouyang, H. Z. Streicher, P. J. Fischinger, R. C. Gallo, C. DeLisi, and J. A Berzofsky. 1987. Helper T cell antigenic site identification in the AIDS virus gp 120 envelope protein and induction of immunity in mice to the native protein using a 16-residue synthetic peptide. Proc. Natl. Acad. Sci. USA. 84:4249-4253.

16. Berzofsky, J. A., A. Bensussan, K. B. Cease, J. F. Bourge, R. Cheynier, Z Lurhuma, J.-J. Salaün, R. C. Gallo, G. M. Shearer, and D. Zagury. 1988. Antigenic peptides recognized by $T$ lymphocytes from AIDS viral envelope-immune humans. Nature (Lond.). 334:706-708.

17. Clerici, M., N. I. Stocks, R. A. Zajac, R. N. Boswell, D. C. Bernstein, D. L.
Mann, G. M. Shearer, and J. A. Berzofsky. 1989. Interleukin-2 production used to detect antigenic peptide recognition by $T$-helper lymphocytes from asymptomatic HIV seropositive individuals. Nature (Lond.). 339:383-385.

18. Hale, P. M., K. B. Cease, R. A. Houghten, C. Ouyang, S. Putney, K Javaherian, H. Margalit, J. L. Cornette, J. L. Spouge, C. DeLisi, and J. A. Berzofsky. 1989. T cell multideterminant regions in the human immunodeficiency virus envelope: toward overcoming the problem of major histocompatibility complex restriction. Int. Immunol. 1:409-415.

19. Benacerraf, B. 1978. A hypothesis to relate the specificity of $T$ lymphocytes and the activity of I region-specific Ir genes in macrophages and B lymphocytes. J. Immunol. 120:1809-1812.

20. Schwartz, R. H. 1985. T-lymphocyte recognition of antigen in association with gene products of the major histocompatibility complex. Annu. Rev. Immunol. 3:237-261.

21. Berzofsky, J. A. 1987. Ir genes: antigen-specific genetic regulation of the immune response. In The Antigens. M. Sela, editor. Academic Press, New York. $1-146$.

22. Schrier, R. D., J. W. Gnann, Jr., R. Landes, C. Lockshin, D. Richman, A McCutchan, C. Kennedy, M. B. A. Oldstone, and J. A. Nelson. 1989. T cell recognition of HIV synthetic peptides in a natural infection. J. Immunol. 142:1166-1176.

23. Callahan, K. M., M. M. Fort, E. A. Obah, E. L. Reinherz, and R. F. Siliciano. 1990. Genetic variability in HIV-1 gp 120 affects interactions with HLA molecules and T cell receptor. $J$. Immunol. 144:3341-3346.

24. Martin, R., D. Jarquemada, M. Flerlage, J. Richert, J. Whitaker, E. O. Long, D. E. McFarlin, and H. F. McFarland. 1990. Fine specificity and HLA restriction of myelin basic protein-specific cytotoxic $\mathrm{T}$ cell lines from multiple sclerosis patients and healthy individuals. J. Immunol. 145:540-548.

25. Martin, R., M. D. Howell, D. Jaraquemada, M. Flerlage, J. Richert, S. Brostoff, E. O. Long, D. E. McFarlin, and H. F. McFarland. 1991. A myelin basic protein peptide is recognized by cytotoxic $T$ cells in the context of four HLA-DR types associated with multiple sclerosis. J. Exp. Med. 173:19-24.

26. Jaraquemada, D., R. Martin, S. Rosen-Bronson, M. Flerlage, H. F. McFarland, and E. O. Long. 1990. HLA-DR2a is the dominant restriction molecule for the cytotoxic T cell response to myelin basic protein in DR2Dw2 individuals. J. Immunol. 145:2880-2885.

27. Sinigaglia, F., M. Guttinger, J. Kilgus, D. M. Doran, H. Matile, H. Etlinger, A. Trzeciak, D. Gillessen, and J. R. L. Pink. 1988. A malaria T-cell epitope recognized in association with most mouse and human MHC class II molecules. Nature (Lond.). 336:778-780.

28. Panina-Bordignon, P., A. Tan, A. Termijtelen, S. Demotz, G. Corradin, and A. Lanzavecchia. 1989. Universally immunogenic T cell epitopes: promiscuous binding to human MHC class II and promiscuous recognition by T cells. Eur. J. Immunol. 19:2237-2242.

29. Brett, S. J., K. B. Cease, C. S. Ouyang, and J. A. Berzofsky. 1989. Fine specificity of $\mathrm{T}$ cell recognition of the same peptide in association with different I-A molecules. J. Immunol. 143:771-779.

30. Guillet, J.-G., M.-Z. Lai, T. J. Briner, S. Buus, A. Sette, H. M. Grey, J. A. Smith, and M. L. Gefter. 1987. Immunological self, nonself discrimination. Science (Wash. DC). 235:865-870.

31. Stewart, J. M., and J. D. Young. 1984. Solid Phase Peptide Synthesis. Pierce Chemical Co., Rockford, IL.

32. Javaherian, K., A. J. Langlois, C. McDanal, K. L. Ross, L. I. Eckler, C. L. Jellis, A. T. Profy, J. R. Rusche, D. P. Bolognesi, S. D. Putney, and T. J. Matthews. 1989. Principal neutralizing domain of the human immunodeficiency virus type 1 envelope protein. Proc. Natl. Acad. Sci. USA. 86:6768-6772.

33. Corradin, G., H. M. Etlinger, and J. M. Chiller. 1977. Lymphocyte specificity in protein antigens. I. Characterization of the antigen-induced in vitro $T$ cell-dependent proliferative response with lymph node cells from primed mice. $J$. Immunol. 119:1048-1053.

34. Matis, L. A., D. L. Longo, S. M. Hedrick, C. Hannum, E. Margoliash, and R. H. Schwartz. 1983. Clonal analysis of the major histocompatibility complex restriction and the fine specificity of antigen recognition in the $T$ cell proliferative response to cytochrome c. J. Immunol. 130:1527-1535.

35. Clerici, M., N. I. Stocks, R. A. Zajac, R. N. Boswell, D. R. Lucey, C. S. Via, and G. M. Shearer. 1989. Detection of three distinct patterns of $T$ helper cell dysfunction in asymptomatic, human immunodeficiency virus-seropositive patients: independence of CD4 cell numbers and clinical staging. J. Clin. Invest. 84:1892-1899.

36. Ratner, L., W. Haseltine, R. Patarca, K. J. Livak, B. Starcich, S. F. Josephs, E. R. Doran, J. A. Rafalski, E. A. Whitehorn, K. Baumeister, L. Ivanoff, S. R. Petteway, Jr., M. L. Pearson, J. A. Lautenberger, T. S. Papas, J. Ghrayeb, N. T. Chang, R. C. Gallo, and F. Wong-Staal. 1985. Complete nucleotide sequence of the AIDS virus HTLV-III. Nature (Lond). 313:277-284.

37. Brett, S. J., K. B. Cease, and J. A. Berzofsky. 1988. Influences of antigen processing on the expression of the T cell repertoire: evidence of MHC-specific hindering structures on the products of processing. J. Exp. Med. 168:357-373.

38. Gammon, G., N. Shastri, J. Cogswell, S. Wilbur, S. Sadegh-Nasseri, U. 
Krzych, A. Miller, and E. E. Sercarz. 1987. The choice of T-cell epitopes utilized on a protein antigen depends on multiple factors distant from as well as at the determinant site. Immunol. Rev. 98:53-73.

39. Vacchio, M. S., J. A. Berzofsky, U. Krzych, J. A. Smith, R. J. Hodes, and A. Finnegan. 1989. Sequences outside a minimal immunodominant site exert negative effects on recognition by staphylococcal nuclease-specific $T$-cell clones. J. Immunol. 143:2814-2819.

40. Berzofsky, J. A., S. J. Brett, H. Z. Streicher, and H. Takahashi. 1988 Antigen processing for presentation to $T$ lymphocytes: Function, mechanisms, and implications for the T-cell repertoire. Immunol. Rev. 106:5-31.

41. Lamb, J. R., D. D. Eckels, P. Lake, J. N. Woody, and N. Green. 1982. Human $T$ cell clones recognize chemically synthesized peptides of influenza hemagglutinin. Nature (Lond.). 300:66-69.

42. Hurwitz, J. L., E. Heber-Katz, C. J. Hackett, and W. J. Gerhard. 1984 Characterization of the murine TH response to influenza virus hemagglutinin: evidence for three major specificities. J. Immunol. 133:3371-3377.

43. Good, M. F., W. L. Maloy, M. N. Lunde, H. Margalit, J. L. Cornette, G. L. Smith, B. Moss, L. H. Miller, and J. A. Berzofsky. 1987. Construction of a synthetic immunogen: use of a new T-helper epitope on malaria circumsporozoite protein. Science (Wash. DC). 235:1059-1062.

44. Good, M. F., D. Pombo, I. A. Quakyi, E. M. Riley, R. A. Houghten, A Menon, D. W. Alling, J. A. Berzofsky, and L. H. Miller. 1988. Human T cel recognition of the circumsporozoite protein of Plasmodium falciparum. Immunodominant $\mathrm{T}$ cell domains map to the polymorphic regions of the molecule. Proc. Natl. Acad. Sci. USA. 85:1199-1203.

45. Dontfraid, F., M. A. Cochran, D. Pombo, J. D. Knell, I. Quakyi, S. Kumar, R. A. Houghten, J. A. Berzofsky, L. H. Miller, and M. F. Good. 1988 Human and murine CD4 T-cell epitopes map to the same region of the malaria circumsporozoite protein: limited immunogenicity of sporozoites and circumsporozoite protein. Mol. Biol. \& Med. 5:185-196.

46. Lane, H. C., J. M. Depper, W. C. Greene, G. Whalen, T. A. Waldmann, and A. S. Fauci. 1985. Qualitative analysis of immune function in patients with the acquired immunodeficiency syndrome: evidence for a selective defect in soluble antigen recognition. $N$. Engl. J. Med. 313:79-84.

46a. Clerici, M., J. A. Berzofsky, G. M. Shearer, and C. O. Tacket. 1991. Exposure to HIV-1 indicated by HIV-specific $T$ helper cell responses before detection of infection by polymerase chain reaction and serum antibodies. J. Infect. Dis. 164:178-182.

47. Myers, G., S. F. Josephs, J. A. Berzofsky, A. B. Rabson, T. F. Smith, and F. Wong-Staal. 1989. Human retroviruses and AIDS 1989. Los Alamos National Laboratory, Los Alamos, NM.

48. DeLisi, C., and J. A. Berzofsky. 1985. T cell antigenic sites tend to be amphipathic structures. Proc. Natl. Acad. Sci. USA. 82:7048-7052.

49. Spouge, J. L., H. R. Guy, J. L. Cornette, H. Margalit, K. Cease, J. A Berzofsky, and C. DeLisi. 1987. Strong conformational propensities enhance T-cell antigenicity. J. Immunol. 138:204-212.

50. Margalit, H., J. L. Spouge, J. L. Cornette, K. Cease, C. DeLisi, and J. A. Berzofsky. 1987. Prediction of immunodominant helper T-cell antigenic sites from the primary sequence. J. Immunol. 138:2213-2229.

51. Cornette, J. L., H. Margalit, C. DeLisi, and J. A. Berzofsky. 1989. Concepts and methods in the identification of $T$ cell epitopes and their use in the construction of synthetic vaccines. Methods Enzymol. 178:611-634.

52. Morrison, L. A., A. E. Lukacher, V. L. Braciale, D. P. Fan, and T. J. Braciale. 1986. Differences in antigen presentation to MHC class I and class II-restricted influenza virus specific cytolytic T lymphocyte clones. J. Exp. Med. 163:903-921

53. Germain, R. N. 1986. The ins and outs of antigen processing and presentation. Nature (Lond.). 322:687-689.

54. Takahashi, H., T. Takeshita, B. Morein, S. D. Putney, R. N. Germain, and J. A. Berzofsky. 1990. Induction of $\mathrm{CD}^{+}$cytotoxic T cells by immunization with purified HIV-1 envelope protein in ISCOMs. Nature (Lond.). 344:873-875.

55. Deres, K., H. Schild, K. H. Wiesmüller, G. Jung, and H. G. Rammensee. 1989. In vivo priming of virus-specific cytotoxic $T$ lymphocytes with synthetic lipopeptide vaccine. Nature (Lond.). 342:561-564. 